\title{
Maxillary Sinus Floor Augmentation With or Without Barrier Membrane Coverage of the Lateral Window: a Systematic Review and Meta-Analysis
}

\author{
Thomas Starch-Jensen'1, Daniel Deluiz², Kirsten Duch ${ }^{3}$, Eduardo Muniz Barretto Tinoco ${ }^{2}$ \\ ${ }^{1}$ Department of Oral and Maxillofacial Surgery, Aalborg University Hospital, Aalborg, Denmark \\ ${ }^{2}$ Department of Periodontology, Rio de Janeiro State University, Rio de Janeiro, Brazil. \\ ${ }^{3}$ Unit of Clinical Biostatistics, Aalborg University Hospital, Aalborg, Denmark.
}

\author{
Corresponding Author: \\ Thomas Starch-Jensen \\ Department of Oral and Maxillofacial Surgery \\ Aalborg University Hospital \\ 18-22 Hobrovej, DK-9000 Aalborg \\ Denmark \\ Phone: +4597662798 \\ Fax: +4597662825 \\ E-mail: thomas.jensen@rn.dk
}

\begin{abstract}
Objectives: Test the hypothesis of no difference in implant treatment outcomes after maxillary sinus floor augmentation with or without barrier membrane coverage of the lateral window.

Material and Methods: A MEDLINE (PubMed), Embase and Cochrane library search in combination with a hand-search of relevant journals was conducted. Human studies published in English until the $5^{\text {th }}$ of July, 2019 were included. Randomised controlled trials and controlled trials with an observation period of minimum six months were included. Primary outcomes included survival of suprastructures and implants. Secondary outcomes included implant stability quotient, peri-implant marginal bone loss, bone regeneration, patient-reported outcome measures, biologic and mechanical complications.

Results: The electronic search and hand-searching resulted in 1068 entries. Six randomised controlled trials characterised by low to high risk of bias and one controlled trial with high risk of bias fulfilled the inclusion criteria. High implant survival rate was reported with both treatment modalities. Meta-analyses disclosed a mean difference of newly formed bone of $6.4 \%$ (confidence interval $=0$ to 12.9 ) and non-mineralised tissue of $-1.1 \%$ (confidence interval $=-2.7$ to 0.5 ), indicating more newly formed bone and diminished non-mineralised with barrier membrane coverage.

Conclusions: There seem to be no statistically significant differences in implant treatment outcomes after maxillary sinus floor augmentation with or without barrier membrane coverage of the lateral window. However, barrier membrane coverage increases percentage of newly formed bone and diminishes proliferation of non-mineralised tissue. Thus, barrier membrane coverage seems to be beneficial and also preventing displacement of the grafting material.
\end{abstract}

Keywords: alveolar ridge augmentation; dental implants; oral surgical procedures; review; sinus floor augmentation.

\author{
Accepted for publication: 23 December 2019 \\ To cite this article: \\ Starch-Jensen T, Deluiz D, Duch K, Tinoco EMB. \\ Maxillary Sinus Floor Augmentation With or Without Barrier Membrane Coverage of the Lateral Window: a Systematic \\ Review and Meta-Analysis \\ J Oral Maxillofac Res 2019;10(4):e1 \\ URL: http://www.ejomr.org/JOMR/archives/2019/4/e1/v10n4e1.pdf \\ doi: $10.5037 /$ jomr.2019.10401
}




\section{INTRODUCTION}

Maxillary sinus floor augmentation (MSFA) applying the lateral window technique is the most commonly used surgical procedure to increase the alveolar bone height of the posterior maxilla before or in conjunction with implant placement, and the treatment outcome involving different types of grafting materials have been documented in several systematic reviews and meta-analyses [1-8]. Barrier membrane coverage of the lateral window has been recommended to prevent soft tissue interference and improve bone regeneration as well as stabilisation of the grafting material [9-11]. However, barrier membrane coverage of the lateral window is associated with lower vascular supply to the applied grafting material, increased risk of infection and additional cost. Moreover, non-absorbable membranes have to be removed and occasionally lead to complications such as wound dehiscence [11]. Systematic reviews have demonstrated high implant survival rate after MSFA with barrier membrane coverage of the lateral window [12-15]. In addition, increased percentage of vital bone after graft maturation have also been reported with barrier membrane coverage compared with the use of no barrier membrane coverage $[16,17]$. However, further systematic reviews and meta-analyses have concluded that the implant survival rate and amount of vital bone formation were not influenced by barrier membrane coverage [18-21]. Consequently, the effectiveness of barrier membrane coverage of the lateral window in conjunction with MSFA remains disputable. The rationale for this systematic review is therefore to investigate whether barrier membrane coverage of the lateral window in conjunction with MSFA is necessary since the use of a barrier membrane increases the cost of the treatment and involves a risk of contamination and disease transmission as well as they can be refused by patients for religious reasons or because they are in contrast with chosen lifestyle.
The objective of the present systematic review and meta-analysis is therefore to test the hypothesis of no difference in implant treatment outcomes after MSFA with or without barrier membrane coverage of the lateral window.

\section{MATERIAL AND METHODS Protocol and registration}

The present systematic review was conducted in accordance with the Preferred Reporting Items for Systematic reviews and Meta-Analyses (PRISMA) statement for reporting systematic reviews [22]. The PRISMA checklist is outlined in Appendix 1. The methods of analysis and inclusion criteria were specified in advance and documented in a protocol. The review was registered in PROSPERO, an international prospective register of systematic reviews. Registration number: CRD42019139519.

The protocol can be accessed at:

https://www.crd.york.ac.uk/prospero/display record. php?ID=CRD42019139519.

\section{Focus question}

The focus question was developed according to the Patient, Intervention, Comparison and Outcome (PICO) framework as described in Table 1.

Focus question: Are there any differences in implant treatment outcomes after MSFA with or without barrier membrane coverage of the lateral window?

\section{Types of studies and publications}

The present systematic review included randomised controlled trials and controlled trials on humans.

\section{Population}

The included studies of the present systematic review involved healthy adult partially or totally edentulous

Table 1. PICOS guidelines

\begin{tabular}{l|l}
\hline Patient and population (P) & $\begin{array}{l}\text { Healthy adult patients with atrophy of the posterior part of the maxilla receiving maxillary sinus floor } \\
\text { augmentation applying the lateral window technique. }\end{array}$ \\
\hline Intervention (I) & Barrier membrane coverage of the lateral window. \\
\hline Comparator or control group (C) & No barrier membrane coverage of the lateral window. \\
\hline Outcomes (O) & $\begin{array}{l}\text { Primary outcomes included survival of suprastructures and implants. Secondary outcomes included } \\
\text { implant stability quotient, peri-implant marginal bone loss, bone regeneration, patient-reported } \\
\text { outcome measures, biologic and mechanical complications. }\end{array}$ \\
\hline Study design (S) & Randomised controlled trials and controlled trials with an observation period of minimum six months. \\
\hline Focused question & $\begin{array}{l}\text { Are there any differences in implant treatment outcomes after maxillary sinus floor augmentation with } \\
\text { or without barrier membrane coverage of the lateral window? }\end{array}$ \\
\hline
\end{tabular}


patients with atrophy of the posterior part of the maxilla receiving MSFA applying the lateral window technique with or without barrier membrane coverage.

\section{Types of outcome measures}

The primary outcome measures are the most important measures for evaluating of the final implant treatment outcomes. Secondary, outcome measures were also included in the present systematic review as surrogate measures.

The primary outcome measures included:

- Survival of suprastructures. Loss of suprastructure was defined as a total loss because of a mechanical and/or biological complication.

- Survival of implants. Loss of implants was defined as mobility of previously clinically osseointegrated implants and removal of nonmobile implants due to progressive peri-implant marginal bone loss and infection.

Moreover, the following secondary outcome measures were assessed:

- Implant stability quotient. Estimated by resonance frequency analysis.

- Peri-implant marginal bone loss. Evaluated by radiographic measurements.

- Bone regeneration. Percentage of newly formed bone, non-mineralized tissue and residual graft material as evaluated by radiographic or histologic measurements.

- Patient-reported outcome measures.

- Biologic and mechanical complications.

\section{Information sources}

The search strategy incorporated examinations of electronic databases, supplemented by a thorough hand-search page by page of relevant journals including "British Journal of Oral and Maxillofacial Surgery", "Clinical Implant Dentistry and Related Research", "Clinical Oral Implants Research", "European Journal of Oral Implantology", "Implant Dentistry", "International Journal of Oral and Maxillofacial Implants", "International Journal of Oral and Maxillofacial Surgery", "International Journal of Periodontics and Restorative Dentistry", "International Journal of Prosthodontics", "Journal of Clinical Periodontology", "Journal of Dental Research", "Journal of Oral Implantology", "Journal of Oral \& Maxillofacial Research", "Journal of Periodontology", "Journal of Prosthetic Dentistry", "Journal of Craniofacial Surgery", "Journal of Cranio-Maxillo-Facial Surgery", "Journal of Oral and Maxillofacial Surgery", "Periodontology 2000", "Oral and Maxillofacial Surgery" and "Oral Surgery Oral Medicine Oral Pathology Oral Radiology". The manual search also included the bibliographies of all articles selected for full-text screening as well as previously published reviews relevant for the present systematic review.

\section{Search}

A MEDLINE (PubMed), Embase, and Cochrane Library search was conducted. Human studies published in English until the $5^{\text {th }}$ of July, 2019 were included. The search strategy was performed in collaboration with a librarian and utilized a combination of Medical subject heading (MeSH) and free text terms. The search strategy is outlined in Appendices $2, \underline{3}$ and $\underline{4}$.

\section{Selection of studies}

The titles of the identified reports were initially screened. The abstract was assessed when the title indicated that the study was relevant. Fulltext analysis was obtained for those with apparent relevance or when the abstract was unavailable. The references of the identified papers were cross-checked for unidentified articles.

\section{Study eligibility}

The inclusion criteria were developed using the PICOS guidelines (Table 1).

\section{Inclusion criteria}

The review exclusively focused on studies with an observation period of minimum six months after MSFA. In addition, at least five patients should be included in the study and the number of sinus augmentation procedures must be clearly specified.

\section{Exclusion criteria}

Studies with implant placement in medically compromised patients as well as studies with insufficient description of the performed numbers of surgical procedures or length of observation period were excluded. Moreover, letters, editorials, $\mathrm{PhD}$ theses, letters to the editor, case reports, abstracts, technical reports, conference proceedings, animal or in vitro studies and literature review papers were also excluded. 


\section{Data extraction}

Data were extracted according to a data-collection form ensuring systematic recording of the outcome measures. In addition, relevant characteristics of the study were recorded. The corresponding author was contacted by e-mail in the absence of important information or uncertainties.

\section{Data items}

The following items were collected from the included articles and arranged in the following fields: author, year of publication, study design, number of patients, MSFA procedures, residual alveolar bone height, type of grafting material, membrane, number of implants, prosthetic solution, length of observation period, survival of suprastructure and implants, implant stability quotient, peri-implant marginal bone loss, bone regeneration, biologic and mechanical complications.

\section{Assessment of methodological quality}

The quality assessment of the included studies was undertaken as part of the data extraction process. A methodological quality rating system was used and the classification of the risk of bias potential for each study was based on the following five criteria [1, $\underline{2}]$ :

1. Random selection in the population (yes/no).

2. Definition of inclusion, exclusion criteria (yes/no).

3. Report of losses to follow-up (yes/no).

4. Validated measurements (yes/no).

5. Statistical analysis (yes/no).

The studies were grouped according to:

1. Low risk of bias (plausible bias unlikely to seriously alter the results) if all above-described quality criteria were met.

2. Moderate risk of bias (plausible bias that weakens confidence in the results) when one of these criteria were not included.

3. High risk of bias (plausible bias that seriously weakens confidence in the results) when two or more criteria were missing.

\section{Statistical analysis}

Meta-analyses were to be conducted only if there were studies of similar comparison, reporting identical outcome measures. However, the included studies of the meta-analysis revealed variations in study design, i.e. size of the lateral window, residual height of the alveolar process, dimension of the sinus cavity, use of nonresorbable and resorbable membranes, dissimilar grafting material, bone cores for histomorphometric analysis were retrieved at different locations, types of outcome measures, length of the graft healing period and observation period. Therefore, a well-defined meta-analysis was not applicable. However, the percentage of newly formed bone and non-mineralised tissue across comparable studies were analysed in a meta-analysis. Forest plots were drawn to show a summary of the histomorphometric characteristics and expressed as the mean difference (MD) between MSFA with barrier membrane coverage of the lateral window and without barrier membrane coverage with the mean expressed in percentage. The 95\% confidence interval (CI) was also calculated. Parametric data were expressed as mean and standard deviation (M $[\mathrm{SD}])$. Statistical significance level was defined at $\mathrm{P}=0.05$.

\section{Assessment of heterogeneity}

The significance of any discrepancies in the estimates of the treatment effects of the different studies was assessed by means of Cochran's test for heterogeneity and the $\mathrm{I}^{2}$ statistic, which describes the percentage of total variation across studies that is due to heterogeneity rather than chance. Heterogeneity was considered statistically significant if $\mathrm{P}<0.1$. A rough guide to the interpretation of $\mathrm{I}^{2}$ given in the Cochrane Handbook for Systematic Reviews of Interventions is as follows: (1) at $0-40 \%$ the heterogeneity might not be important, (2) $30-60 \%$ may represent moderate heterogeneity, (3) 50 - 90\% may represent substantial heterogeneity, and (4) $75-100 \%$ may represent considerable heterogeneity [23]].

\section{RESULTS \\ Study selection}

Article review and data extraction were performed according to the PRISMA flow diagram (Figure 1). The electronic search resulted in 1067 entries. One article was identified through hand-searching [16]. Of these 1068 articles, 427 were excluded because they had been retrieved in more than one search. A total of 31 abstracts were reviewed and full-text analysis included 12 articles. Finally, seven studies were included in the present systematic review $[\underline{16}, \underline{17}$, 24-28].

\section{Exclusion of studies}

The reasons for excluding studies after full-text assessment were as follows: retrospective study 


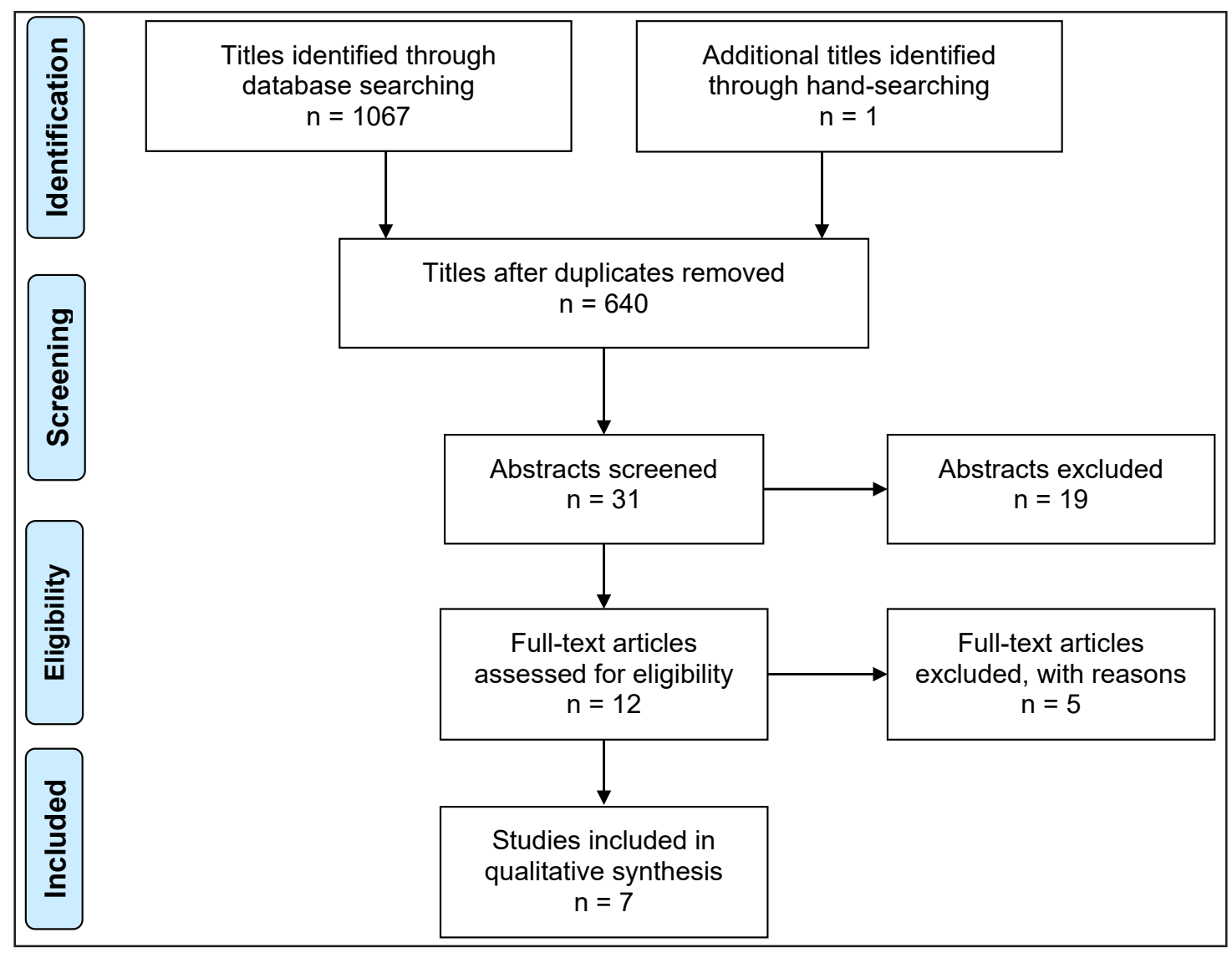

Figure 1. PRISMA flow diagram demonstrating the results of the systematic literature search.

without a control group [29], MSFA with two-window technique [30]. Moreover, three studies could not be excluded before meticulous reading [31-33].

\section{Study characteristics}

The included studies of the present systematic review consisted of six randomised controlled trials $[\underline{16}, \underline{17}, \underline{24}, \underline{26-28}]$ and one controlled clinical trial [25]. A split-mouth study design was used in three randomized controlled trials $[\underline{17}, \underline{26}, \underline{28}]$. Partially and totally edentulous patients with horizontal deficiencies of the maxillary alveolar ridge were enrolled in the included studies. No significant difference in patient demographics were reported in two studies $[\underline{27}, \underline{28}]$. Inclusion and exclusion criteria were specified in all the included studies $[16,17,24-28]$. Patients with controlled diabetes were not excluded in three studies $[16,17,25]$ and smoking habits were not excluded in six studies $[\underline{16}, \underline{17}, \underline{24}, \underline{25}, \underline{27}, \underline{28}]$. The residual bone height was described in three studies $[\underline{24}, \underline{27}, \underline{28}]$. Power calculation was performed in one study [28]. CONSORT guidelines were followed in one study [27]. Randomisation was conducted using a computer generated random allocation process $[27,28]$ or no information was provided about the randomisation procedure $[\underline{16}, \underline{17}, \underline{24}, \underline{26}]$. The surgical procedure was performed by the same surgeon [28], two surgeons [27] or no information was provided about the number of surgeons involved in the study $[16,17,24-$ 26]. Dimension of the lateral window was measured in one study [27]. Various grafting materials were used involving OsteoGraf $/ \mathrm{N}^{\circledR}$ (CeraMed, Lakewood, Colorado, USA) alone or in combination with varying percentages of autogenous bone or demineralized freeze-dried bone allograft [16], Bio-Oss ${ }^{\circledR}$ (Geistlich Pharma AG, Wolhusen, Switzerland) [24,28], Bio$\mathrm{Oss}^{\circledR}$ (Osteohealth Co., Shirley, NY, US) alone or in combination with a maximum of $20 \%$ autogenous bone graft from the maxillary tuberosity or ascending mandibular ramus [25], mixture of $50 \%$ particulated autogenous bone graft from the lateral bone wall and $50 \%$ collagenated corticocancellous porcine bone (MP3 ${ }^{\circledR}$; Osteobiol-Tecnoss, Coazze, Italy) [27], Bio-Oss $^{\circledR}$ (Osteohealth, Newport Beach, California, USA) [26] or various grafting materials [17]. Different barrier membranes were used to cover the lateral window involving non-resorbable expanded polytetrafluoroethylene (e-PTFE) membrane (Goretex Augmentation Material, 3i, W. L. Gore) $[\underline{16}, \underline{17}, \underline{25}]$ or resorbable collagen Bio-Gide ${ }^{\circledR}$ membrane (Geistlich Pharma AG, Wolhusen, Switzerland) [24,28], BioGide $^{\circledR}$ membrane (Osteohealth Co., Shirley, New York, USA) [25] (Osteohealth, Newport Beach, 
California, USA) [26], and Evolution (OsteobiolTecnoss, Torino, Italy) [27]. Fixation of the covering barrier membrane was conducted in six studies $[\underline{16}, \underline{17}, \underline{24-26}, \underline{28}]$. Frios $^{\circledR}$ tacks (Friadent $\mathrm{GmbH}$, Mannheim, Germany) were used in one study [24], while no information was provided in five studies about the used tacks $[16,17,25,26,28]$. MSFA with delayed implant placement were performed in three studies after 6 to 10 months of graft healing [2527]. MSFA involving both immediate and delayed implant placement was performed in four studies $[\underline{16}, \underline{17}, \underline{24}, \underline{28}]$. Different implant systems were used including screw-type machined-surface implants (Brånemark System ${ }^{\circledR}$; Nobel Biocare, Gothenburg, Sweden) [24] and Osseotite ${ }^{\circledR}$ (Biomet 3i Inc., Palmbeach, Florida, USA) [28]. The used implant system was not specified in five studies $[16,17,25-$ 27]. Histomorphometric parameters were assessed in six studies [16,25-28], after six months [27,28], 6 to 9 months [16], 6 to 10 months [25], eight months [26] or 7 to 13 months [17], respectively. The bone cores were retrieved with trephine drill through the previous lateral window $[\underline{16}, \underline{17}, \underline{25-27}]$ or at implant placement sites [28]. None of the included studies provided information about training or calibration of the examiners assessing the clinical and radiographic outcome. Information about blinding assessment was described in one study [28]. Numbers of drop outs were described in two studies $[26,27]$. Survival of suprastructures, implant stability quotient, periimplant marginal bone loss and patient-reported outcome measures was not reported in any of the included studies. Thus, these outcome measures are not described in the following section or outlined in Table 2.

\section{Outcome measures}

The result of each outcome measure is presented first and then a short summary is finally provided. The results of the outcome measures are outlined in Table 2.

\section{Survival of implants}

Survival of implants with a non-resorbable covering barrier membrane (e-PTFE) was 99\% compared with $96 \%$ without a membrane [16]. No statistical analysis was performed [16].

Survival of implants with a non-resorbable covering barrier membrane (e-PTFE) was $100 \%$ compared with $93 \%$ without a membrane, after 0 to 5 years [17]. No statistical analysis was performed [17].

Survival of implants with a resorbable covering collagen barrier membrane (Bio-Gide ${ }^{\circledR}$ ) was 93\% compared with $78 \%$ without a membrane, after 12 40 months [24]. No statistical analysis was performed. There was no difference in implant failure rate between MSFA with immediate or delayed implant placement when membrane coverage of the lateral window was performed. While, an increased implant failure rate was reported after MSFA and immediate implant placement without barrier membrane coverage of the lateral window [24].

Survival of implants after MSFA with a resorbable collagen covering barrier membrane $\left(\right.$ Bio-Gide ${ }^{\circledR}$ ) or a non-resorbable covering barrier membrane (e-PTFE) was $98 \%$ compared with $100 \%$ without a membrane, after one year of functional implant loading [25]. No statistical analysis was performed [25].

Survival of implants after MSFA with a resorbable covering collagen barrier membrane (Bio-Gide ${ }^{\circledR}$ ) was $96 \%$ compared with $94 \%$ without a membrane, after one year of functional implant loading [28]. There was no statistically significant difference in implant survival rate between the two treatment modalities $(P=0.08)$. However, immediate implant placement revealed a statistically significant higher implant failure rate compared with delayed implant placement $(P=0.04)[28]$.

\section{Summary}

MSFA with or without barrier membrane coverage of the lateral window seems not to significantly influence the implant survival rate. However, a higher percentage of implant failures were reported after MSFA without barrier membrane coverage and immediate implant placement.

\section{Bone regeneration}

Percentage of newly formed bone after MSFA with a non-resorbable covering barrier membrane (e-PTFE) varied between 17 - 33\% compared with $9-19 \%$ without a membrane, after 6 to 9 months [16]. No statistical analysis was performed [16].

Percentage of newly formed bone after MSFA with a non-resorbable covering barrier membrane (e-PTFE) was $26(15) \%$ compared with $11(8) \%$ without a membrane, after 7 to 13 months [17]. No statistical analysis was performed [17].

Percentage of newly formed bone, non-mineralised tissue and residual graft material after MSFA with a non-resorbable covering barrier membrane (e-PTFE) was $17 \%, 51 \%$ and $32 \%$, after 6 to 10 months, respectively [25]. Resorbable covering collagen barrier membrane $\left(\right.$ Bio-Gide ${ }^{\circledR}$ ) revealed $18 \%, 56 \%$ and $26 \%$. 
Table 2. Maxillary sinus floor augmentation with or without barrier membrane coverage of the lateral window

\begin{tabular}{|c|c|c|c|c|c|c|c|c|c|c|c|c|c|c|c|}
\hline \multirow{3}{*}{ Study } & \multirow{3}{*}{$\begin{array}{c}\text { Year of } \\
\text { publication }\end{array}$} & \multirow{3}{*}{$\begin{array}{l}\text { Study } \\
\text { design }\end{array}$} & \multirow{3}{*}{ NOP } & \multicolumn{7}{|c|}{ Materials and methods } & \multicolumn{5}{|c|}{ Outcome measures } \\
\hline & & & & \multirow[t]{2}{*}{ MSFA } & \multirow{2}{*}{$\begin{array}{l}\text { RBH } \\
(\mathbf{m m})\end{array}$} & \multirow{2}{*}{$\begin{array}{c}\text { Type of grafting } \\
\text { material }\end{array}$} & \multirow[t]{2}{*}{ Membrane } & \multirow{2}{*}{$\begin{array}{c}\text { Number of } \\
\text { implants }\end{array}$} & \multirow{2}{*}{$\begin{array}{c}\text { Prosthetic } \\
\text { solution }\end{array}$} & \multirow{2}{*}{$\begin{array}{c}\text { LOP } \\
\text { (month) }\end{array}$} & \multirow{2}{*}{\begin{tabular}{|c|}
$\begin{array}{c}\text { Survival of } \\
\text { implants } \\
(\%)\end{array}$ \\
\end{tabular}} & \multicolumn{3}{|c|}{$\begin{array}{c}\text { Bone regeneration } \\
(\%)\end{array}$} & \multirow{2}{*}{$\begin{array}{c}\text { Biologic and } \\
\text { mechanical } \\
\text { complications }\end{array}$} \\
\hline & & & & & & & & & & & & NFB & NMT & RG & \\
\hline \multirow{2}{*}{ Froum et al. [16] } & \multirow[b]{2}{*}{1998} & \multirow[b]{2}{*}{$\mathrm{RCT}$} & \multirow[b]{2}{*}{113} & \multirow[b]{2}{*}{113} & \multirow[b]{2}{*}{ NR } & \multirow{2}{*}{$\begin{array}{c}\text { Combination of } \\
\text { different grafting } \\
\text { materials }\end{array}$} & e-PTFE: 79 & 133 & \multirow[b]{2}{*}{ NR } & \multirow{2}{*}{$6-9$} & \begin{tabular}{|l|l}
99 \\
\end{tabular} & $17-33$ & \multirow{2}{*}{\multicolumn{2}{|c|}{ NR }} & \multirow[b]{2}{*}{ NR } \\
\hline & & & & & & & No membrane coverage: 34 & 82 & & & 96 & $9-19$ & & & \\
\hline \multirow{2}{*}{ Tarnow et al. [17] } & \multirow{2}{*}{2000} & \multirow{2}{*}{$\begin{array}{l}\text { RCT, } \\
\text { split- } \\
\text { mouth }\end{array}$} & \multirow{2}{*}{12} & \multirow{2}{*}{12} & $N R$ & $\begin{array}{c}\text { Combination of } \\
\text { different orafting }\end{array}$ & e-PTFE: 12 & 28 & NR & $7-13$ & 100 & $\begin{array}{c}26 \\
\text { (SD 15) } \\
\end{array}$ & $\mathrm{N}$ & IR & NR \\
\hline & & & & & & materials & No membrane coverage: 12 & 27 & NR & $1-13$ & 93 & $\begin{array}{c}12 \\
(\mathrm{SD} 8)\end{array}$ & $\mathrm{N}$ & R & NR \\
\hline Tawil et al. [24] & 2001 & RCT & 29 & 30 & $4-8$ & Bio-Oss $^{\circledR}: 100 \%$ & $\begin{array}{c}\begin{array}{c}\text { Collagen } \\
\text { membrane: } 15\end{array} \\
\end{array}$ & 29 & $\begin{array}{l}\text { Fixed } \\
\text { prostheses }\end{array}$ & $\begin{array}{c}22.4 \\
(12-40)\end{array}$ & 93 & & NR & & Mucosal tears: 5 \\
\hline & & & & & & & No membrane coverage: 15 & 32 & & & 78 & & & & \\
\hline & & & & 21 & & & \begin{tabular}{|c|} 
e-PTFE: 21 \\
\end{tabular} & 46 & & & 98 & 17 & 51 & 32 & \\
\hline $\begin{array}{l}\text { Wallace et al. } \\
{[25]}\end{array}$ & 2005 & $\mathrm{CCT}$ & 51 & 37 & NR & $\begin{array}{l}\text { Bio-Oss }{ }^{8}: 100 \% \\
\text { PABG: } 20 \% \text { and } \\
\text { Bi-OSs. }\end{array}$ & $\begin{array}{c}\text { Collagen } \\
\text { membrane: } 37\end{array}$ & 83 & NR & 12 & 98 & 18 & 56 & 26 & NR \\
\hline & & & & 6 & & & No membrane coverage: 6 & 6 & & & 100 & 12 & 64 & 24 & \\
\hline & & $\mathrm{RCT}$ & & & & & Collagen membrane: 6 & & & & & $13^{\mathrm{a}}$ & $36^{\mathrm{b}}$ & $50^{\mathrm{c}}$ & None \\
\hline Choi et al. [26] & 2009 & $\begin{array}{c}\text { split- } \\
\text { mouth }\end{array}$ & 6 & 12 & NR & Bio-Oss $^{\circledR}: 100 \%$ & No membrane coverage: 6 & NR & NR & $\begin{array}{c}8 \\
(7-9)\end{array}$ & NR & 12 & 55 & 33 & $\begin{array}{l}\text { Dehiscence: } 1 \text {; } \\
\text { swelling: } 1\end{array}$ \\
\hline Porone et ol [27] & 2013 & $\mathrm{PCT}$ & 18 & 18 & $<5$ & PABG: $50 \%$ & Collagen membrane: 9 & NR & NP & 6 & NR & $\left(\begin{array}{c}31 \\
\text { SD 16) }\end{array}\right.$ & $\begin{array}{c}51 \\
(\mathrm{SD} 19)\end{array}$ & $\begin{array}{c}18 \\
(\mathrm{SD} 20)\end{array}$ & $\begin{array}{c}\text { SMP: } 1 ; \\
\text { dehiscence: } 1 \text {; } \\
\text { haematoma: } 2\end{array}$ \\
\hline Barone et al. [27] & 2013 & RCT & 18 & 18 & $<5$ & $\mathrm{MP}^{\circledR}: 50 \%$ & No membrane coverage: 9 & NR & NR & 6 & NR & $\mid \begin{array}{c}28 \\
(\mathrm{SD} 19)\end{array}$ & $\begin{array}{c}59 \\
(\mathrm{SD} 15)\end{array}$ & $\begin{array}{c}13 \\
(\mathrm{SD} 12)\end{array}$ & $\begin{array}{c}\text { SMP: } 2 ; \\
\text { dehiscence: } 1 \text {; } \\
\text { haematoma: } 2\end{array}$ \\
\hline García-Denche & 2013 & RCT, & 100 & 66 & $4-7$ & $\mathrm{Bin}=\mathrm{cs}^{\circledR} \cdot 100^{\circ}$ & Collagen membrane: 66 & 278 & \begin{tabular}{|c|} 
Fixed \\
nrostheses or
\end{tabular} & 12 & $96.1^{\mathrm{d}}$ & \begin{tabular}{|c|}
19 \\
$(\mathrm{SD} 6)^{\mathrm{e}}$ \\
\end{tabular} & $\begin{array}{c}31 \\
(\mathrm{SD} 3)^{\mathrm{f}} \\
\end{array}$ & $\begin{array}{c}49 \\
(\mathrm{SD} 10)^{\mathrm{g}} \\
\end{array}$ & None \\
\hline et al. [28] & 2013 & $\begin{array}{c}\text { split- } \\
\text { mouth }\end{array}$ & 109 & 69 & $4-1$ & B10-USS: $: 100 \%$ & No membrane coverage: 69 & 218 & $\begin{array}{l}\text { prostneses or } \\
\text { bar retention }\end{array}$ & & 94.2 & \begin{tabular}{c|}
15 \\
(SD 5)
\end{tabular} & $\begin{array}{c}32 \\
(\mathrm{SD} 6)\end{array}$ & $\begin{array}{c}56 \\
(\mathrm{SD} 21)\end{array}$ & $\begin{array}{c}\text { Displacement of } \\
\text { grafting material: } 4\end{array}$ \\
\hline
\end{tabular}

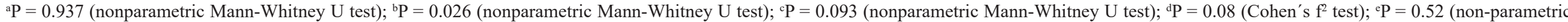
Wilcoxon t-test); ${ }^{\mathrm{f}} \mathrm{P}=1$ (non-parametric Wilcoxon t-test); ${ }^{\mathrm{g}} \mathrm{P}=0.6$ (non-parametric Wilcoxon t-test).

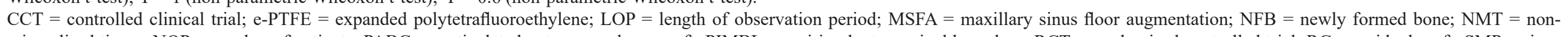

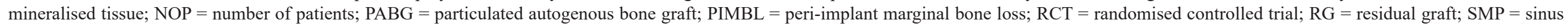
membrane perforation; $\mathrm{SD}=$ standard deviation. 
Corresponding measurements for no barrier membrane coverage was $12 \%, 64 \%$ and $24 \%$. No statistical analysis was performed, but a higher percentage of newly formed bone and diminished percentage of non-mineralised tissue was observed after MSFA with barrier membrane coverage of the lateral window [25].

Percentage of newly formed bone, non-mineralised tissue and residual graft material after MSFA with a resorbable covering collagen barrier membrane (BioGide $^{\circledR}$ ) was $13 \%, 36 \%$ and $50 \%$, after eight months, respectively [26]. Corresponding measurements without a membrane was $12 \%, 55 \%$ and $33 \%$. There were no statistically significant differences in the new bone formation $(\mathrm{P}=0.937)$ and residual grafting material $(\mathrm{P}=0.093)$ after MSFA with or without barrier membrane coverage of the lateral window. However, the average percentage of non-mineralised tissue was statistically significant higher without barrier membrane coverage $(P=0.026)$ compared with barrier membrane coverage of the lateral window [26].

Percentage of newly formed bone, non-mineralised tissue and residual graft material after MSFA with a resorbable covering collagen barrier membrane (Evolution) was $31(16) \%, 51(19) \%$ and $18(20) \%$, after six months, respectively [27]. Corresponding measurements without a membrane was $28(19) \%$, $59(15) \%$ and $13(12) \%$. There was no statistically significant difference in the histomorphometric outcome after MSFA with or without barrier membrane coverage of the lateral window $(\mathrm{P}=0.82)$, but a decreased percentage of non-mineralised tissue was observed with barrier membrane coverage [27]. Percentage of newly formed bone, non-mineralised tissue and residual graft material after MSFA with a covering barrier membrane (Bio-Gide ${ }^{\circledR}$ ) was $19(6) \%$, $31(3) \%$ and $49(10) \%$, after six months, respectively [28]. Corresponding measurements without a membrane was $15(5) \%, 32(6) \%$ and $56(21) \%$. There was no statistically significant difference in newly formed bone ( $\mathrm{P}=0.52)$, non-mineralised tissue $(\mathrm{P}=1)$ or residual graft material $(\mathrm{P}=0.6)$ [28].

\section{Meta-analysis}

Meta-analysis (with random effect) where conducted to combine data from multiple studies where similar effects were measured. However meta-analysis can only be conducted for continuous data if both the mean and standard deviation (SD) are available of the percentage of newly formed bone and nonmineralised tissue. Thus only three studies $[\underline{17}, \underline{27}, \underline{28}]$ met the inclusion requirement for the meta-analysis and the remaining studies [16, $\underline{24-26}]$ were excluded from the meta-analysis. One of the included studies [17] did not measure the mean percentage of nonmineralised tissue and thus two studies were included in the meta-analysis of non-mineralised tissue and three studies were included in the meta-analysis of newly formed bone. Random effect analysis and test for heterogeneity was inconclusive due to the limited number of studies included. No statistically significant difference in heterogeneity between the included studies was found for newly formed bone $\left(\mathrm{I}^{2}=0 \%, \mathrm{P}=0.803\right)[17,27,28]$, and non-mineralised tissue $\left(\mathrm{I}^{2}=49 \%, \mathrm{P}=0.14\right)[\underline{27}, \underline{28}]$. Meta-analysis showed a mean difference of newly formed bone of $6.4 \%$ (confidence interval $[\mathrm{CI}]=0$ to 12.9 ) (Figure 2) and non-mineralised tissue of $-1.1 \%(\mathrm{CI}=-2.7$ to 0.5 ) (Figure 3) demonstrating no statistically significant differences in newly formed bone and nonmineralised tissue after MSFA with or without barrier membrane coverage of the lateral window. However, MSFA with barrier membrane coverage of the lateral window seems to be associated with an overall higher percentage of newly formed bone and diminish nonmineralised tissue compared with the use of no barrier membrane coverage.

\section{Summary}

Histomorphometric evaluation revealed no statistically significant differences in percentage of newly formed bone and non-mineralised tissue after MSFA with or without barrier membrane coverage of the lateral window. However, a higher percentage of

\begin{tabular}{|c|c|c|c|c|c|c|c|c|}
\hline \multicolumn{2}{|l|}{ Study } & \multicolumn{3}{|c|}{ Mean Difference } & & MD & \multicolumn{2}{|c|}{ 95\% Cl Weight } \\
\hline Tarnow et al.[18] & & & & $\longrightarrow$ & & 13.6 & $4.3 ; 22.9]$ & $27.3 \%$ \\
\hline Barone et al. [27] & & & & & & 2.6[ & -13.6; 18.8] & $12.7 \%$ \\
\hline Garcia et al. [28] & & & + & & & $4.0^{\circ}$ & [ $2.1 ; 5.9]$ & $60.0 \%$ \\
\hline \multirow{3}{*}{$\begin{array}{l}\text { Random errects model } \\
\text { Hetrog. } I^{2}=49 \%, p=0.14\end{array}$} & & & 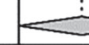 & $\sum$ & & \multirow{3}{*}{\multicolumn{2}{|c|}{$6.4[0.0 ; 12.9]$}} & $100.0 \%$ \\
\hline & $\Gamma$ & 1 & & 1 & $\neg$ & & & \\
\hline & -20 & -10 & 0 & 10 & 20 & & & \\
\hline
\end{tabular}

Figure 2. Meta-analysis using a random effect model assessing newly formed bone. 


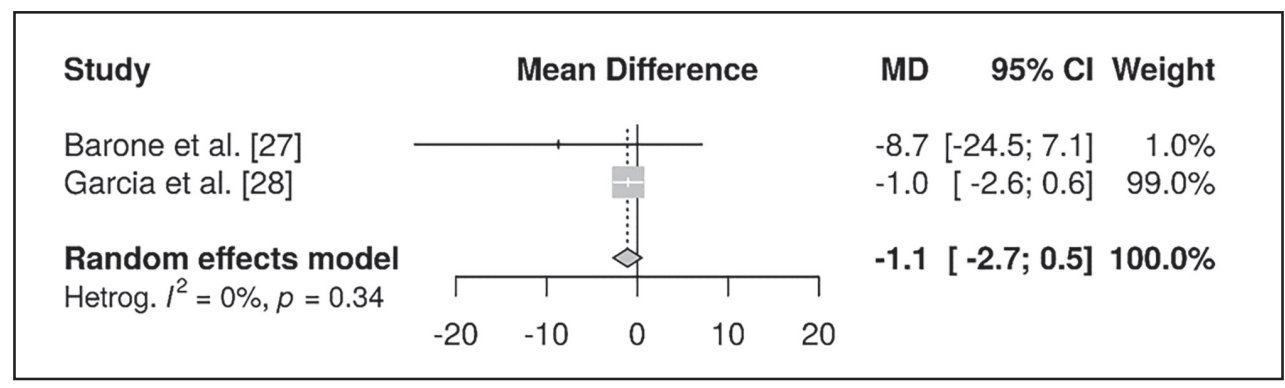

Figure 3. Meta-analysis using a random effect model assessing non-mineralised tissue.

newly formed bone and diminished non-mineralised tissue was observed with barrier membrane coverage of the lateral window compared with no barrier membrane coverage.

\section{Biologic and mechanical complications}

Mucosal tears were observed in five patients after MSFA [24]. No information was provided about the mucosal tears were related to the use of barrier membrane coverage of the lateral window [24].

Biologic complications involving soft tissue wound dehiscence and unexplained postoperative swelling was described in two patients after MSFA without barrier membrane coverage of the lateral window [26]. The complications were solved with antibiotic treatment [26].

Sinus membrane perforation occurred in both groups and was successfully treated with a resorbable collagen membrane [27]. Mild haematoma and soft tissue wound dehiscence also occurred in both groups. There was no difference in the frequency of biologic complications between the two treatment modalities [27].

Unexplained pain occurred in three patients that resolved after treatment with Clindamycin [28]. Partial loss of grafting material into the subcutaneous space of the maxillary ridge occurred in four patients after MSFA without barrier membrane coverage of the lateral window [료].

\section{Summary}

Biologic and mechanical complications after MSFA were not reported in all included studies, but when reported, they were generally infrequent and not severe. Perforation of the sinus membrane was the most frequent intraoperative complication, but this does not seem to influence the final implant treatment outcome. Frequency of mucosal tears and soft tissue wound dehiscence seem to be comparable between the two treatment modalities. However, displacement of the grafting material into the subcutaneous space was only reported after MSFA without barrier membrane coverage of the lateral window.

\section{Quality assessment}

The quality of the included studies is summarised in Table 3 . The controlled trial was characterised by high risk of bias [25]. Two randomised controlled trials were characterised by low risk of bias [26,27], one with moderate risk of bias [28], and three with high risk of bias $[16,17,24]$.

\section{DISCUSSION}

The objective of the present systematic review and meta-analysis was to test the hypothesis of no difference in implant treatment outcomes after MSFA with or without barrier membrane coverage of

Table 3. Quality assessment of included studies

\begin{tabular}{l|c|c|c|c|c|c}
\hline \multicolumn{1}{c|}{ Study } & $\begin{array}{c}\text { Random selection } \\
\text { in the population }\end{array}$ & $\begin{array}{c}\text { Definition of inclusion } \\
\text { and exclusion criteria }\end{array}$ & $\begin{array}{c}\text { Report of losses } \\
\text { to follow-up }\end{array}$ & $\begin{array}{c}\text { Validated } \\
\text { measurements }\end{array}$ & $\begin{array}{c}\text { Statistical } \\
\text { analysis }\end{array}$ & $\begin{array}{c}\text { Risk of } \\
\text { bias }\end{array}$ \\
\hline Froum et al. [16] & Yes & Yes & No & Yes & No & High \\
\hline Tarnow et al. [17] & Yes & Yes & No & Yes & No & High \\
\hline Tawil et al. [24] & Yes & Yes & No & Yes & No & High \\
\hline Wallace et al. [25] & No & Yes & No & Yes & No & High \\
\hline Choi et al. [26] & Yes & Yes & Yes & Yes & Low \\
\hline Barone et al. [27] & Yes & Yes & Yes & Yes & Yes & Low \\
\hline García-Denche et al. [28] & Yes & Yes & Yes & Yes & Moderate \\
\hline
\end{tabular}


the lateral window. The electronic search and handsearching resulted in 1068 entries. One controlled trial [25] with high risk of bias and six randomised controlled trials $[16,17,24, \underline{26-28}]$ characterised by low $[26,27]$, moderate [28] and high risk of bias $[16,17,24]$, fulfilled the inclusion criteria and were included in the final synthesis.

The result of the present systematic review and metaanalysis demonstrated no statistically significant difference in implant survival rate, newly formed bone or non-mineralised tissue after MSFA with or without barrier membrane coverage of the lateral window. However, barrier membrane coverage of the lateral window generally increases the percentage of newly formed bone and diminishes proliferation of non-mineralised tissue. Thus, MSFA with barrier membrane coverage of the lateral window seems to be beneficial and improve bone regeneration. However, considerable variations in study design, small patient samples and type of outcome measures as well as various methodological confounding factors posed serious restrictions to review the literature in a quantitative systematic manner. Hence, the conclusions drawn from the results of the present systematic review should be interpreted with extreme caution and well-designed randomised controlled trials with larger patient samples are needed before definite conclusions can be provided about the effectiveness of barrier membrane coverage of the lateral window in conjunction with MSFA.

The included studies of the present systematic review revealed a tendency towards higher percentage of newly formed bone and diminished non-mineralised tissue after MSFA with barrier membrane coverage of the lateral window compared with no barrier membrane coverage [16, 17, 25-28]. Moreover, soft tissue adherence to the graft particles and infiltration of connective tissue into the grafting material was reported after MSFA without barrier membrane coverage of the lateral window [26]. However, the histomorphometric outcome after MSFA with or without barrier membrane coverage are influences by numerous factors including the dimension of the lateral window, volume of the maxillary sinus cavity, type of grafting material and the residual alveolar bone height [34-36]. A statistically significant higher percentage of newly formed bone and diminished non-mineralised tissue have been reported after MSFA with reduced dimension of the lateral window compared with larger dimension [34]. In the present systematic review, the dimension of the lateral window was measured in one of the included studies demonstrating higher percentage of newly formed bone and diminishes non- mineralised tissue with barrier membrane coverage compared with no membrane coverage, when the dimension of the lateral window was equivalent [27]. Consequently, the histomorphometric outcome is improved after MSFA with barrier membrane coverage when the dimension of the lateral window is equivalent.

Recent studies have demonstrated that the percentage of newly formed bone is inversely proportional to the bucco-palatal distance of the maxillary sinus. Thus, the volume of the maxillary sinus cavity also influences the amount of bone regeneration [36-39]. However, none of the included studies of the present systematic review evaluated the dimension of the maxillary sinus cavity or standardised the quantity of the grafting material.

A recent systematic review and meta-analysis assessing histomorphometric variables after MSFA concluded that autogenous bone graft revealed the highest amount of newly formed bone compared with other grafting materials [35]. The included studies of the present systematic review used dissimilar grafting materials and the histomorphometric outcome are thus not factual comparable. Consequently, histomorphometric outcome after MSFA is influenced by several confounding factors, which is not taken into account in the present systematic review.

A newly published retrospective study concluded that MSFA with barrier membrane coverage of the lateral window diminishes postoperative displacement of the grafting material and prevents bone substitutes particles from penetrating within the buccal mucosa [40]. One of the included studies of the present systematic review reported displacement of the grafting material into the subcutaneous space after MSFA without barrier membrane coverage [28]. Haemorrhage and swelling of the Schneiderian membrane after MSFA combined with the physiologically positive air pressure of the maxillary sinus may cause displacement of the grafting material through the lateral window, if the lateral window is left uncovered $[2 \underline{28}, \underline{40}]$. Thus, it is important that patients are instructed not to blow their nose and sneeze with open mouth after MSFA without barrier membrane coverage of the lateral window.

Changes in Schneiderian membrane thickness after MSFA have previously been assessed by cone beam computed tomography demonstrating a transient swelling of the Schneiderian membrane, which reaches the highest value one week after surgery and completely resolves over months $[41,42]$. The use of a larger graft volume was positively correlated with an increase in postoperative Schneiderian membrane 
thickness [41]. Moreover, a recent computed tomographic study demonstrated that displacement of the grafting material was also influenced by the used volume of the grafting material [40]. Consequently, MSFA without barrier membrane coverage of the lateral window is associated with an increased risk of postoperatively displacement of the grafting material due to transient swelling of the Schneiderian membrane, size of the lateral window and volume of the grafting material. Thus, membrane coverage of the lateral window seems to stabilise and prevent displacement of the grafting material.

Systematic reviews provide a meticulous summary of the current evidence related to a research question or hypothesis. Meta-analysis is the statistical synthesis of the results included in the systematic review. The strength of evidence from a systematic review and meta-analysis is therefore related to the quality of the included studies. High quality randomised controlled trials with low risk of bias provide the highest level of evidence for ascertaining the safety and efficacy of a specific surgical intervention. The histomorphometric outcome of the present systematic review and meta-analysis is based on one randomised controlled trials with low risk of bias [27], one with moderate risk of bias [28], and one with high risk of bias [17]. Consequently, the current level of evidence is inadequate to propose implications for evidence based clinical guidelines according to the focus question of the present systematic review.

\section{CONCLUSIONS}

The present systematic review and meta-analysis revealed no statistically significant difference in implant treatment outcomes after maxillary sinus floor augmentation with or without barrier membrane coverage of the lateral window. However, barrier membrane coverage increases percentage of newly formed bone, diminish proliferation of nonmineralised tissue and prevent displacement of the grafting material. Thus, barrier membrane coverage of the lateral window seems to be beneficial and improve implant treatment outcomes. However, small patient samples, dissimilar evaluation methods, different outcome measures and various methodological confounding factors posed serious restrictions reviewing the literature in a quantitative systematic manner. Hence, the conclusions drawn from the results of the present systematic review should be interpreted with extreme caution and well-designed randomised controlled trials that follow Consolidated Standards of Reporting Trials (CONSORT) guidelines are needed before definite conclusions can be provided about the effectiveness of barrier membrane coverage of the lateral window.

\section{ACKNOWLEDGMENTS AND DISCLOSURE STATEMENTS}

The authors report no conflicts of interest related to this study.

\section{REFERENCES}

1. Starch-Jensen T, Aludden H, Hallman M, Dahlin C, Christensen AE, Mordenfeld A. A systematic review and metaanalysis of long-term studies (five or more years) assessing maxillary sinus floor augmentation. Int J Oral Maxillofac Surg. 2018 Jan;47(1):103-116. [Medline: 28545806] [doi: 10.1016/j.ijom.2017.05.001]

2. Starch-Jensen T, Mordenfeld A, Becktor JP, Jensen SS. Maxillary Sinus Floor Augmentation With Synthetic Bone Substitutes Compared With Other Grafting Materials: A Systematic Review and Meta-analysis. Implant Dent. 2018 Jun;27(3):363-374. [Medline: 29771732] [doi: 10.1097/ID.0000000000000768]

3. Starch-Jensen T, Jensen JD. Maxillary Sinus Floor Augmentation: a Review of Selected Treatment Modalities. J Oral Maxillofac Res. 2017 Sep 30;8(3):e3. [Medline: 29142655] [PMC free article: 5676313] [doi: 10.5037/jomr.2017.8303]

4. Jensen T, Schou S, Stavropoulos A, Terheyden H, Holmstrup P. Maxillary sinus floor augmentation with Bio-Oss or Bio-Oss mixed with autogenous bone as graft: a systematic review. Clin Oral Implants Res. 2012 Mar;23(3):263-73. [Medline: 21443592] [doi: 10.1111/j.1600-0501.2011.02168.x]

5. Raghoebar GM, Onclin P, Boven GC, Vissink A, Meijer HJA. Long-term effectiveness of maxillary sinus floor augmentation: A systematic review and meta-analysis. J Clin Periodontol. 2019 Jun;46 Suppl 21:307-318. [Medline: 30624789] [doi: 10.1111/jcpe.13055]

6. Antonoglou GN, Stavropoulos A, Samara MD, Ioannidis A, Benic GI, Papageorgiou SN, Sándor GK. Clinical Performance of Dental Implants Following Sinus Floor Augmentation: A Systematic Review and Meta-Analysis of Clinical Trials with at Least 3 Years of Follow-up. Int J Oral Maxillofac Implants. 2018 May/Jun;33(3):e45-e65. [Medline: 29763503] [doi: 10.11607/jomi.6417]

7. Yang J, Xia T, Wang H, Cheng Z, Shi B. Outcomes of maxillary sinus floor augmentation without grafts in atrophic maxilla: A systematic review and meta-analysis based on randomised controlled trials. J Oral Rehabil. 2019 Mar;46(3):282-290. [Medline: 30537184] [doi: 10.1111/joor.12753] 
8. Esposito M, Grusovin MG, Rees J, Karasoulos D, Felice P, Alissa R, Worthington H, Coulthard P. Effectiveness of sinus lift procedures for dental implant rehabilitation: a Cochrane systematic review. Eur J Oral Implantol. 2010 Spring;3(1):7-26. [Medline: 20467595]

9. McAllister BS, Margolin MD, Cogan AG, Taylor M, Wollins J. Residual lateral wall defects following sinus grafting with recombinant human osteogenic protein-1 or Bio-Oss in the chimpanzee. Int J Periodontics Restorative Dent. 1998 Jun;18(3):227-39. [Medline: 9728105]

10. Wallace SS, Tarnow DP, Froum SJ, Cho SC, Zadeh HH, Stoupel J, Del Fabbro M, Testori T. Maxillary sinus elevation by lateral window approach: evolution of technology and technique. J Evid Based Dent Pract. 2012 Sep;12(3 Suppl):161-71. [Medline: 23040346] [doi: 10.1016/S1532-3382(12)70030-1]

11. Gassling V, Purcz N, Braesen JH, Will M, Gierloff M, Behrens E, Açil Y, Wiltfang J. Comparison of two different absorbable membranes for the coverage of lateral osteotomy sites in maxillary sinus augmentation: a preliminary study. J Craniomaxillofac Surg. 2013 Jan;41(1):76-82. [Medline: 23218506] [doi: 10.1016/j.jcms.2012.10.015]

12. Ting M, Rice JG, Braid SM, Lee CYS, Suzuki JB. Maxillary Sinus Augmentation for Dental Implant Rehabilitation of the Edentulous Ridge: A Comprehensive Overview of Systematic Reviews. Implant Dent. 2017 Jun;26(3):438-464. [Medline: 28520572] [doi: 10.1097/ID.0000000000000606]

13. Wallace SS, Froum SJ. Effect of maxillary sinus augmentation on the survival of endosseous dental implants. A systematic review. Ann Periodontol. 2003 Dec;8(1):328-43. [Medline: 14971260] [doi: 10.1902/annals.2003.8.1.328]

14. Duttenhoefer F, Souren C, Menne D, Emmerich D, Schön R, Sauerbier S. Long-term survival of dental implants placed in the grafted maxillary sinus: systematic review and meta-analysis of treatment modalities. PLoS One. 2013 Sep 18;8(9):e75357. [Medline: 24058679] [PMC free article: 3776785] [doi: 10.1371/journal.pone.0075357]

15. Pjetursson BE, Tan WC, Zwahlen M, Lang NP. A systematic review of the success of sinus floor elevation and survival of implants inserted in combination with sinus floor elevation. J Clin Periodontol. 2008 Sep;35(8 Suppl):216-40. [Medline: 18724852] [doi: 10.1111/j.1600-051X.2008.01272.x]

16. Froum SJ, Tarnow DP, Wallace SS, Rohrer MD, Cho SC. Sinus floor elevation using anorganic bovine bone matrix (OsteoGraf/N) with and without autogenous bone: a clinical, histologic, radiographic, and histomorphometric analysis-Part 2 of an ongoing prospective study. Int J Periodontics Restorative Dent. 1998 Dec;18(6):528-43. [Medline: 10321168$]$

17. Tarnow DP, Wallace SS, Froum SJ, Rohrer MD, Cho SC. Histologic and clinical comparison of bilateral sinus floor elevations with and without barrier membrane placement in 12 patients: Part 3 of an ongoing prospective study. Int J Periodontics Restorative Dent. 2000 Apr;20(2):117-25. [Medline: 11203554]

18. Nkenke E, Stelzle F. Clinical outcomes of sinus floor augmentation for implant placement using autogenous bone or bone substitutes: a systematic review. Clin Oral Implants Res. 2009 Sep;20 Suppl 4:124-33. [Medline: 19663959] [doi: 10.1111/j.1600-0501.2009.01776.x]

19. Suárez-López Del Amo F, Ortega-Oller I, Catena A, Monje A, Khoshkam V, Torrecillas-Martínez L, Wang HL, GalindoMoreno P. Effect of barrier membranes on the outcomes of maxillary sinus floor augmentation: a meta-analysis of histomorphometric outcomes. Int J Oral Maxillofac Implants. 2015 May-Jun;30(3):607-18. [Medline: 25671628] [doi: $10.11607 /$ jomi.3886]

20. Klijn RJ, Meijer GJ, Bronkhorst EM, Jansen JA. A meta-analysis of histomorphometric results and graft healing time of various biomaterials compared to autologous bone used as sinus floor augmentation material in humans. Tissue Eng Part B Rev. 2010 Oct;16(5):493-507. [Medline: 20334505] [doi: 10.1089/ten.teb.2010.0035]

21. Klijn RJ, Meijer GJ, Bronkhorst EM, Jansen JA. Sinus floor augmentation surgery using autologous bone grafts from various donor sites: a meta-analysis of the total bone volume. Tissue Eng Part B Rev. 2010 Jun;16(3):295-303. [Medline: 19958168] [doi: 10.1089/ten.teb.2009.0558]

22. Welch V, Petticrew M, Tugwell P, Moher D, O’Neill J, Waters E, White H; PRISMA-Equity Bellagio group. PRISMAEquity 2012 extension: reporting guidelines for systematic reviews with a focus on health equity. PLoS Med. 2012;9(10):e1001333. [Medline: 23222917] [PMC free article: 3484052] [doi: 10.1371/journal.pmed.1001333]

23. Higgins JPT, Altman DG, Sterne JAC. Chapter 8: assessing risk of bias in included studies. In: Higgins JPT, Green S, editors. Cochrane handbook for systematic reviews of interventions version 5.1.0 (updated March 2011). The Cochrane Collaboration. 2011. [URL: http://handbook.cochrane.org/]

24. Tawil G, Mawla M. Sinus floor elevation using a bovine bone mineral (Bio-Oss) with or without the concomitant use of a bilayered collagen barrier (Bio-Gide): a clinical report of immediate and delayed implant placement. Int J Oral Maxillofac Implants. 2001 Sep-Oct;16(5):713-21. [Medline: 11669254]

25. Wallace SS, Froum SJ, Cho SC, Elian N, Monteiro D, Kim BS, Tarnow DP. Sinus augmentation utilizing anorganic bovine bone (Bio-Oss) with absorbable and nonabsorbable membranes placed over the lateral window: histomorphometric and clinical analyses. Int J Periodontics Restorative Dent. 2005 Dec;25(6):551-9. [Medline: 16353530]

26. Choi KS, Kan JY, Boyne PJ, Goodacre CJ, Lozada JL, Rungcharassaeng K. The effects of resorbable membrane on human maxillary sinus graft: a pilot study. Int J Oral Maxillofac Implants. 2009 Jan-Feb;24(1):73-80. [Medline: 19344028]

27. Barone A, Ricci M, Grassi RF, Nannmark U, Quaranta A, Covani U. A 6-month histological analysis on maxillary sinus augmentation with and without use of collagen membranes over the osteotomy window: randomized clinical trial. Clin Oral Implants Res. 2013 Jan;24(1):1-6. [Medline: 22151577] [doi: 10.1111/j.1600-0501.2011.02340.x] 
28. García-Denche JT, Wu X, Martinez PP, Eimar H, Ikbal DJ, Hernández G, López-Cabarcos E, Fernandez-Tresguerres I, Tamimi F. Membranes over the lateral window in sinus augmentation procedures: a two-arm and split-mouth randomized clinical trials. J Clin Periodontol. 2013 Nov;40(11):1043-51.. [Medline: 24164570] [doi: 10.1111/jepe.12153]

29. Cho YS, Park HK, Park CJ. Bony window repositioning without using a barrier membrane in the lateral approach for maxillary sinus bone grafts: clinical and radiologic results at 6 months. Int J Oral Maxillofac Implants. 2012 Jan-Feb;27(1):211-7. [Medline: 22299099]

30. Yu H, He D, Qiu L. A prospective randomized controlled trial of the two-window technique without membrane versus the solo-window technique with membrane over the osteotomy window for maxillary sinus augmentation. Clin Implant Dent Relat Res. 2017 Dec;19(6):1099-1105. [Medline: 29034598] [doi: 10.1111/cid.12547]

31. Cordaro L, Bosshardt DD, Palattella P, Rao W, Serino G, Chiapasco M. Maxillary sinus grafting with Bio-Oss or Straumann Bone Ceramic: histomorphometric results from a randomized controlled multicenter clinical trial. Clin Oral Implants Res. 2008 Aug;19(8):796-803. [Medline: 18705811] [doi: 10.1111/j.1600-0501.2008.01565.x]

32. Froum SJ, Wallace SS, Elian N, Cho SC, Tarnow DP. Comparison of mineralized cancellous bone allograft (Puros) and anorganic bovine bone matrix (Bio-Oss) for sinus augmentation: histomorphometry at 26 to 32 weeks after grafting. Int J Periodontics Restorative Dent. 2006 Dec;26(6):543-51. [Medline: 17243327]

33. Froum SJ, Wallace SS, Cho SC, Elian N, Tarnow DP. Histomorphometric comparison of a biphasic bone ceramic to anorganic bovine bone for sinus augmentation: 6- to 8-month postsurgical assessment of vital bone formation. A pilot study. Int J Periodontics Restorative Dent. 2008 Jun;28(3):273-81. [Medline: 18605603]

34. Avila-Ortiz G, Wang HL, Galindo-Moreno P, Misch CE, Rudek I, Neiva R. Influence of lateral window dimensions on vital bone formation following maxillary sinus augmentation. Int J Oral Maxillofac Implants. 2012 Sep-Oct;27(5):1230-8. [Medline: 23057039]

35. Danesh-Sani SA, Engebretson SP, Janal MN. Histomorphometric results of different grafting materials and effect of healing time on bone maturation after sinus floor augmentation: a systematic review and meta-analysis. J Periodontal Res. 2017 Jun;52(3):301-312. [Medline: 27534916] [doi: 10.1111/jre.12402]

36. Avila G, Wang HL, Galindo-Moreno P, Misch CE, Bagramian RA, Rudek I, Benavides E, Moreno-Riestra I, Braun T, Neiva R. The influence of the bucco-palatal distance on sinus augmentation outcomes. J Periodontol. 2010 Jul;81(7): 1041-50. [Medline: 20450402] [doi: 10.1902/jop.2010.090686]

37. Stacchi C, Lombardi T, Ottonelli R, Berton F, Perinetti G, Traini T. New bone formation after transcrestal sinus floor elevation was influenced by sinus cavity dimensions: A prospective histologic and histomorphometric study. Clin Oral Implants Res. 2018 May;29(5):465-479. [Medline: 29569763] [doi: 10.1111/clr.13144]

38. Lombardi T, Stacchi C, Berton F, Traini T, Torelli L, Di Lenarda R. Influence of Maxillary Sinus Width on New Bone Formation After Transcrestal Sinus Floor Elevation: A Proof-of-Concept Prospective Cohort Study. Implant Dent. 2017 Apr;26(2):209-216. [Medline: 28125520] [doi: 10.1097/ID.0000000000000554]

39. Soardi CM, Spinato S, Zaffe D, Wang HL. Atrophic maxillary floor augmentation by mineralized human bone allograft in sinuses of different size: an histologic and histomorphometric analysis. Clin Oral Implants Res. 2011 May;22(5):560-6. [Medline: 21143532] [doi: 10.1111/j.1600-0501.2010.02034.x]

40. Ohayon L, Taschieri S, Friedmann A, Del Fabbro M. Bone Graft Displacement After Maxillary Sinus Floor Augmentation With or Without Covering Barrier Membrane: A Retrospective Computed Tomographic Image Evaluation. Int J Oral Maxillofac Implants. 2019 May/June;34(3):681-691. [Medline: 30521657] [doi: 10.11607/jomi.6940]

41. Makary C, Rebaudi A, Menhall A, Naaman N. Changes in Sinus Membrane Thickness After Lateral Sinus Floor Elevation: A Radiographic Study. Int J Oral Maxillofac Implants. 2016 Mar-Apr;31(2):331-7. [Medline: 26478975] [doi: 10.11607/jomi.4108]

42. Guo ZZ, Liu Y, Qin L, Song YL, Xie C, Li DH. Longitudinal response of membrane thickness and ostium patency following sinus floor elevation: a prospective cohort study. Clin Oral Implants Res. 2016 Jun;27(6):724-9. [Medline: 26277876] [doi: 10.1111/clr.12655]

\section{To cite this article:}

Starch-Jensen T, Deluiz D, Duch K, Tinoco EMB.

Maxillary Sinus Floor Augmentation With or Without Barrier Membrane Coverage of the Lateral Window: a Systematic Review and Meta-Analysis

J Oral Maxillofac Res 2019;10(4):e1

URL: http://www.ejomr.org/JOMR/archives/2019/4/e1/v10n4e1.pdf

doi: $10.5037 /$ jomr.2019.10401 
Copyright (C) Starch-Jensen T, Deluiz D, Duch K, Tinoco EMB. Published in the JOURNAL OF ORAL \& MAXILLOFACIAL RESEARCH (http://www.ejomr.org), 30 December 2019.

This is an open-access article, first published in the JOURNAL OF ORAL \& MAXILLOFACIAL RESEARCH, distributed under the terms of the Creative Commons Attribution-Noncommercial-No Derivative Works 3.0 Unported License, which permits unrestricted non-commercial use, distribution, and reproduction in any medium, provided the original work and is properly cited. The copyright, license information and link to the original publication on (http://www.ejomr.org) must be included. 
Appendix 1. PRISMA checklist [22]

\begin{tabular}{|c|c|c|c|}
\hline Section/topic & \# & Checklist item & $\begin{array}{l}\text { Reported } \\
\text { on page \# }\end{array}$ \\
\hline \multicolumn{4}{|l|}{ TITLE } \\
\hline Title & 1 & Identify the report as a systematic review, meta-analysis, or both. & 1 \\
\hline \multicolumn{4}{|c|}{ ( } \\
\hline Structured summary & 2 & $\begin{array}{l}\text { Provide a structured summary including, as applicable: background; objectives; data sources; study } \\
\text { eligibility criteria, participants, and interventions; study appraisal and synthesis methods; results; } \\
\text { limitations; conclusions and implications of key findings; systematic review registration number. }\end{array}$ & 2 \\
\hline \multicolumn{4}{|l|}{ INTRODUCTION } \\
\hline Rationale & 3 & Describe the rationale for the review in the context of what is already known. & 4 \\
\hline Objectives & 4 & $\begin{array}{l}\text { Provide an explicit statement of questions being addressed with reference to participants, interven- } \\
\text { tions, comparisons, outcomes, and study design (PICOS). }\end{array}$ & 4,5 \\
\hline \multicolumn{4}{|l|}{ METHODS } \\
\hline $\begin{array}{l}\text { Protocol and registra- } \\
\text { tion }\end{array}$ & 5 & $\begin{array}{l}\text { Indicate if a review protocol exists, if and where it can be accessed (e.g., Web address), and, if } \\
\text { available, provide registration information including registration number. }\end{array}$ & 6 \\
\hline Eligibility criteria & 6 & $\begin{array}{l}\text { Specify study characteristics (e.g., PICOS, length of follow-up) and report characteristics (e.g., } \\
\text { years considered, language, publication status) used as criteria for eligibility, giving rationale. }\end{array}$ & $6,7,9$ \\
\hline Information sources & 7 & $\begin{array}{l}\text { Describe all information sources (e.g., databases with dates of coverage, contact with study authors } \\
\text { to identify additional studies) in the search and date last searched. }\end{array}$ & 7,8 \\
\hline Search & 8 & $\begin{array}{l}\text { Present full electronic search strategy for at least one database, including any limits used, such that } \\
\text { it could be repeated. }\end{array}$ & 8 \\
\hline Study selection & 9 & $\begin{array}{l}\text { State the process for selecting studies (i.e., screening, eligibility, included in systematic review, } \\
\text { and, if applicable, included in the meta-analysis). }\end{array}$ & 8,9 \\
\hline $\begin{array}{l}\text { Data collection } \\
\text { process }\end{array}$ & 10 & $\begin{array}{l}\text { Describe method of data extraction from reports (e.g., piloted forms, independently, in duplicate) } \\
\text { and any processes for obtaining and confirming data from investigators. }\end{array}$ & 9,10 \\
\hline Data items & 11 & $\begin{array}{l}\text { List and define all variables for which data were sought (e.g., PICOS, funding sources) and any } \\
\text { assumptions and simplifications made. }\end{array}$ & 10 \\
\hline $\begin{array}{l}\text { Risk of bias in indi- } \\
\text { vidual studies }\end{array}$ & 12 & $\begin{array}{l}\text { Describe methods used for assessing risk of bias of individual studies (including specification of } \\
\text { whether this was done at the study or outcome level), and how this information is to be used in any } \\
\text { data synthesis. }\end{array}$ & 10,11 \\
\hline Summary measures & 13 & \begin{tabular}{|l|l} 
State the principal summary measures (e.g., risk ratio, difference in means). & 1
\end{tabular} & Not reporte \\
\hline Synthesis of results & 14 & $\begin{array}{l}\text { Describe the methods of handling data and combining results of studies, if done, including mea- } \\
\text { sures of consistency }\left(\text { e.g., } \mathrm{I}^{2}\right) \text { for each meta-analysis. }\end{array}$ & 12,13 \\
\hline $\begin{array}{l}\text { Risk of bias across } \\
\text { studies }\end{array}$ & 15 & $\begin{array}{l}\text { Specify any assessment of risk of bias that may affect the cumulative evidence (e.g., publication } \\
\text { bias, selective reporting within studies). }\end{array}$ & Not reporte \\
\hline Additional analyses & 16 & $\begin{array}{l}\text { Describe methods of additional analyses (e.g., sensitivity or subgroup analyses, meta-regression), } \\
\text { if done, indicating which were pre-specified. }\end{array}$ & Not report \\
\hline \multicolumn{4}{|l|}{ RESULTS } \\
\hline Study selection & 17 & $\begin{array}{l}\text { Give numbers of studies screened, assessed for eligibility, and included in the review, with reasons } \\
\text { for exclusions at each stage, ideally with a flow diagram. }\end{array}$ & 13 \\
\hline Study characteristics & 18 & $\begin{array}{l}\text { For each study, present characteristics for which data were extracted (e.g., study size, PICOS, } \\
\text { follow-up period) and provide the citations. }\end{array}$ & $13-15$ \\
\hline $\begin{array}{l}\text { Risk of bias within } \\
\text { studies }\end{array}$ & 19 & $\begin{array}{l}\text { Present data on risk of bias of each study and, if available, any outcome level assessment (see item } \\
12 \text { ). }\end{array}$ & 21 \\
\hline $\begin{array}{l}\text { Results of individual } \\
\text { studies }\end{array}$ & 20 & $\begin{array}{l}\text { For all outcomes considered (benefits or harms), present, for each study: (a) simple summary data } \\
\text { for each intervention group (b) effect estimates and confidence intervals, ideally with a forest plot. }\end{array}$ & $15-21$ \\
\hline Synthesis of results & 21 & $\begin{array}{l}\text { Present results of each meta-analysis done, including confidence intervals and measures of con- } \\
\text { sistency. }\end{array}$ & 18,19 \\
\hline $\begin{array}{l}\text { Risk of bias across } \\
\text { studies }\end{array}$ & 22 & Present results of any assessment of risk of bias across studies (see Item 15). & 21 \\
\hline Additional analysis & 23 & $\begin{array}{l}\begin{array}{l}\text { Give results of additional analyses, if done (e.g., sensitivity or subgroup analyses, meta-regression } \\
\text { [see Item 16]). }\end{array}\end{array}$ & Not reporte \\
\hline \multicolumn{4}{|l|}{ DISCUSSION } \\
\hline Summary of evidence & 24 & $\begin{array}{l}\text { Summarize the main findings including the strength of evidence for each main outcome; consider } \\
\text { their relevance to key groups (e.g., healthcare providers, users, and policy makers). }\end{array}$ & 21 \\
\hline Limitations & 25 & $\begin{array}{l}\text { Discuss limitations at study and outcome level (e.g., risk of bias), and at review-level (e.g., incom- } \\
\text { plete retrieval of identified research, reporting bias). }\end{array}$ & 21,22 \\
\hline Conclusions & 26 & $\begin{array}{l}\text { Provide a general interpretation of the results in the context of other evidence, and implications for } \\
\text { future research. }\end{array}$ & 24,25 \\
\hline \multicolumn{4}{|l|}{ FUNDING } \\
\hline Funding & 27 & $\begin{array}{l}\text { Describe sources of funding for the systematic review and other support (e.g., supply of data); role } \\
\text { of funders for the systematic review. }\end{array}$ & 25 \\
\hline
\end{tabular}


Appendix 2. PubMed search until the $5^{\text {th }}$ of July, 2019

\begin{tabular}{c|c|l|c}
\hline Search & $\begin{array}{c}\text { Add to } \\
\text { builder }\end{array}$ & \multicolumn{1}{|c|}{ Query } & $\begin{array}{l}\text { Items } \\
\text { found }\end{array}$ \\
\hline$\underline{\# 48}$ & $\underline{\text { Add }}$ & $\begin{array}{l}\text { Search }((((\text { Osteotomy[tw] OR lateral[tw] OR window[tw])) AND }((((\text { “Sinus Floor Augmentation”[Mesh]) OR } \\
((((\text { "Maxillary Sinus”[Mesh]) OR Maxillary Sinus[Text Word]) OR sinus floor[Text Word])) AND ((“Bone } \\
\text { Transplantation”[Mesh]) OR }((\text { transplant*[Text Word] OR augmentat*[Text Word] OR elevat*[Text Word] OR } \\
\text { graft*[Text Word] OR lift*[Text Word] }))))) \text { AND membrane*[Text Word]))) }\end{array}$ & $\underline{469}$ \\
\hline
\end{tabular}

Appendix 3. Embase search until the $5^{\text {th }}$ of July, 2019

\begin{tabular}{c|l|c}
\hline No. & \multicolumn{1}{|c|}{ Query } & Results \\
\hline$\# 15$ & $\# 10$ AND \#13 AND \#14 & 442 \\
\hline$\# 14$ & osteotomy:ti,ab,kw,de OR lateral:ti,ab,kw,de OR window*:ti,ab,kw,de & 512091 \\
\hline$\# 13$ & $\# 11$ OR \#12 & 1381887 \\
\hline$\# 12$ & 'artificial membrane'/exp & 47221 \\
\hline$\# 11$ & membran**:ti,ab,kw,de & 1380557 \\
\hline$\# 10$ & $\# 1$ OR \#9 & 3339 \\
\hline$\# 9$ & $\# 5$ AND \#8 & 3339 \\
\hline$\# 8$ & $\# 6$ OR \#7 & 1939869 \\
\hline$\# 7$ & transplant*:ti,ab,kw OR augmentat*:ti,ab,kw OR graft*:ti,ab,kw OR elevat*:ti,ab,kw OR lift*:ti,ab,kw & 1920983 \\
\hline$\# 6$ & 'bone transplantation'/exp & 51406 \\
\hline$\# 5$ & $\# 2$ OR \#3 OR \#4 & 17891 \\
\hline$\# 4$ & (sinus NEAR/2 floor):ti,ab,kw,de & 2001 \\
\hline$\# 3$ & ((maxilla* OR maxillar*) NEAR/2 sinus):ti,ab,kw,de & 17442 \\
\hline$\# 2$ & 'maxillary sinus'/exp & 12055 \\
\hline$\# 1$ & 'sinus floor augmentation'/exp & 991 \\
\hline
\end{tabular}

Appendix 4. Cochrane Library search until the $5^{\text {th }}$ of July, 2019

\begin{tabular}{c|l|c}
\hline ID & \multicolumn{1}{|c|}{ Search } & Hits \\
\hline$\# 1$ & MeSH descriptor: [Sinus Floor Augmentation] explode all trees & 134 \\
\hline$\# 2$ & ((maxiilla* OR maxillary) NEAR/2 Sinus) & 613 \\
\hline$\# 3$ & sinus NEAR/2 floor & 338 \\
\hline$\# 4$ & $\# 2$ OR \#3 & 712 \\
\hline$\# 5$ & MeSH descriptor: [Bone Transplantation] explode all trees & 886 \\
\hline$\# 6$ & transplant* OR augmentat* OR graft* OR elevat* OR lift* & 108626 \\
\hline$\# 7$ & $\# 5$ OR \#6 & 108626 \\
\hline$\# 8$ & $\# 4$ AND \#7 & 456 \\
\hline$\# 9$ & $\# 1$ OR \#8 & 456 \\
\hline$\# 10$ & MeSH descriptor: [Membranes, Artificial] explode all trees & 1174 \\
\hline$\# 11$ & membrane* & 16574 \\
\hline$\# 12$ & $\# 10$ OR \#11 & 16908 \\
\hline$\# 13$ & osteotomy OR lateral OR window* & 20494 \\
\hline$\# 14$ & $\# 9$ AND \#13 AND \#13 & 156 \\
\hline
\end{tabular}

